Journal of the Arkansas Academy of Science

\title{
Long-term Monitoring and Recovery of a Population of Alligator Snapping Turtles, Macrochelys temminckii (Testudines: Chelydridae), from a Northeastern Arkansas Stream
}

\author{
S. E. Trauth \\ Arkansas State University, strauth@astate.edu \\ D. S. Siegel \\ Southeast Missouri State University \\ M. L. McCallum \\ Langston University \\ D. H. Jamieson \\ Crowder College-Cassville
}

\begin{abstract}
A. Holt

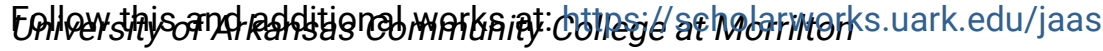

Part of the Population Biology Commons, and the Zoology Commons
\end{abstract}

See next page for additionai authors

\section{Recommended Citation}

Trauth, S. E.; Siegel, D. S.; McCallum, M. L.; Jamieson, D. H.; Holt, A.; Trauth, J. B.; Hicks, H.; Stanley, J. W.; Elston, J.; Kelly, J. J.; and Konvalina, J. D. (2016) "Long-term Monitoring and Recovery of a Population of Alligator Snapping Turtles, Macrochelys temminckii (Testudines: Chelydridae), from a Northeastern Arkansas Stream," Journal of the Arkansas Academy of Science: Vol. 70 , Article 39.

DOI: https://doi.org/10.54119/jaas.2016.7031

Available at: https://scholarworks.uark.edu/jaas/vol70/iss1/39

This article is available for use under the Creative Commons license: Attribution-NoDerivatives 4.0 International (CC BY-ND 4.0). Users are able to read, download, copy, print, distribute, search, link to the full texts of these articles, or use them for any other lawful purpose, without asking prior permission from the publisher or the author.

This Article is brought to you for free and open access by ScholarWorks@UARK. It has been accepted for inclusion in Journal of the Arkansas Academy of Science by an authorized editor of ScholarWorks@UARK. For more information, please contact scholar@uark.edu. 
Long-term Monitoring and Recovery of a Population of Alligator Snapping Turtles, Macrochelys temminckii (Testudines: Chelydridae), from a Northeastern

Arkansas Stream

Authors

S. E. Trauth, D. S. Siegel, M. L. McCallum, D. H. Jamieson, A. Holt, J. B. Trauth, H. Hicks, J. W. Stanley, J. Elston, J. J. Kelly, and J. D. Konvalina 


\title{
Long-term Monitoring and Recovery of a Population of Alligator Snapping Turtles, Macrochelys temminckii (Testudines: Chelydridae), from a Northeastern Arkansas Stream
}

\author{
S.E. Trauth ${ }^{1 *}$, D.S. Siegel ${ }^{2}$, M.L. McCallum ${ }^{3}$, D.H. Jamieson ${ }^{4}$, A. Holt ${ }^{5}$, J.B. Trauth $^{6}$, H. Hicks ${ }^{7}$, \\ J.W. Stanley ${ }^{1}$, J. Elston ${ }^{8}$, J.J. Kelly ${ }^{9}$, and J.D. Konvalina ${ }^{1}$ \\ ${ }^{1}$ Department of Biological Sciences, Arkansas State University, State University, AR 72467-0599 \\ ${ }^{2}$ Department of Biology, Southeast Missouri State University, One University Plaza, MS 6200, Cape Girardeau, MO 63701 \\ ${ }^{3}$ School of Agriculture and Applied Sciences, Langston University, Langston, OK 73050 \\ ${ }^{4}$ Biology Department, Crowder College-Cassville, 4020 North Main, Cassville, MO 65625 \\ ${ }^{5}$ University of Arkansas Community College at Morrilton, 1537 University Blvd., Morrilton, AR 72110 \\ ${ }^{6} 2213$ Byrnewood, Jonesboro, AR 72404 \\ ${ }^{7} 4106$ Maple Street, North Little Rock, AR 72118 \\ ${ }^{8} 4400$ West University Blvd., Apartment 14201, Dallas, TX 75209 \\ ${ }^{9} 7351$ Hoover, Apartment 3N, Richmond Heights, MO 63117
}

*Correspondence: strauth@astate.edu

Running Title: Long-term Monitoring of Alligator Snapping Turtles

\section{Abstract}

We conducted a mark-recapture study of Alligator Snapping Turtles, Macrochelys temminckii, on Salado Creek (Independence Co., Arkansas) during 10 trapping seasons, which spanned a 20-year period (1995-2015). We trapped a total of 163 Alligator Snapping Turtles during 416 trap nights and recorded a total of 35 recaptures during this study. Both the catch per unit effort (CPUE) and Jolly-Seber approaches demonstrated that this population benefitted from removal of harvest pressure, thus leading to an increase in abundance of Alligator Snapping Turtles in the lower $\sim 5 \mathrm{~km}$ of the creek. The CPUE averaged slightly greater than 0.24 (317 trap nights) during the first 4 years (1995-1998). The CPUE also showed an increase to 0.64 by 2001 (only 14 trap nights), and then dramatically increased during the final 5 years to 0.92 (85 trap nights). The population size estimates during the early period of the study (1995-2001) ranged from 20 turtles in 1995 to as many as 88 turtles in 1998, whereas the population size estimates from 2011-2015 ranged from 105 turtles in 2011 to as many as 282 turtles in 2015. Within our sample, recaptured males grew faster on average than females or juveniles in both straight carapace length and mass. These data, however, should be used with caution as age was not known. Most of the recaptured Alligator Snapping Turtles exhibited some degree of site fidelity.

\section{Introduction}

The Alligator Snapping Turtle, Macrochelys temminckii, is North America's largest freshwater turtle. As a long-lived species, males greatly outweigh females and can often reach a massive body size (e.g., greater than $120 \mathrm{~kg}$; Pritchard 2006). Because turtle meat has long been a culinary staple for humans worldwide (Liner 2005), the conservation status of Alligator Snapping Turtles has become a paramount issue in recent years. Decades of widespread exploitation by commercial trappers on this species in several southern states has led to an apparent overharvesting of this turtle (Pritchard 1989), which subsequently brought about its current protection and legal status throughout most of its distribution (Reed et al. 2002).

Species recovery is a complex and case-specific process, often requiring conservation actions that attempt to offset the drivers of extinction (Hoffmann et al. 2010). Management of long-lived organisms, such is the case with species of chelydrid turtles poses a particularly difficult monitoring challenge (Congdon et al. 1994, Reed et al. 2002). For example, short-term investigations of populations of snapping turtles may be hampered simply because the animals themselves may outlive their field studies (Gibbs and Steen 2005). Long-term investigations, on the other hand, may require sampling protocols that extend well beyond the lifespan of researchers (Reed et al. 2002). Long-term investigations, however, are especially important 
because they provide information on life history parameters that can affect management decisions related to turtle populations subjected to commercial harvesting (Congdon et al. 1994).

Long-term field studies on Alligator Snapping Turtles were initiated in the early 1990s in Arkansas and Missouri in response to reports by their game and fish agencies (Wagner et al. 1994-Arkansas Game and Fish Commission; Santhuff 1993-Missouri Department of Conservation) indicating declines in populations. These studies revealed depressed population numbers; however, both states lacked sufficient information on the population ecology of this species to adequately address management concerns. Consequently, each state set forth to create a population database to better understand the species status.

In Arkansas, Trauth et al. (1998) conducted a preliminary short-term study (1995-1997; 352 trap nights yielding 98 turtles), which examined the population structure of Alligator Snapping Turtles in 3 northeastern Arkansas creeks. They reported size-class differences in 2 of the 3 creeks and attributed a lack of adult turtles to previous harvesting. Howey and Dinkelacker (2013) trapped 103 turtles in a central Arkansas stream from 2005 to 2007 and found several factors impeding population recovery. In 2009, Lescher et al. (2013) re-trapped six sites previously documented by Santhuff (1993) in Missouri and found significantly fewer turtles at all 6 locations. Shipman and Riedle (2008), in another study in southeastern Missouri, captured 37 turtles from 4 sites (out of 19 visited) in 2 counties. They found a significant difference

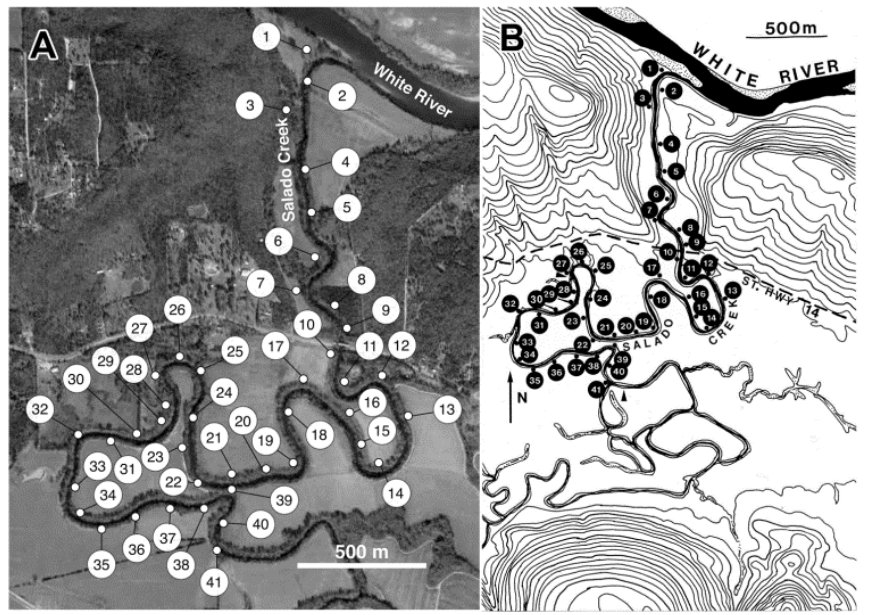

Figure 1. Designated trapping locations superimposed onto physiographic (A) and topographic (B) images of lower Salado Creek, Independence Co., Arkansas. Arrowhead (in B) points to an unnavigable region of the creek. (Image in A derived from Google Earth $^{\odot}$ ). Cultivated agricultural fields (pale areas in A) immediately surround much of the lower region of the creek. in turtle size when comparing turtles taken from historic collection sites exploited by commercial trappers vs. non-historic, unexploited sites. Additional status and/or distributional surveys in other states (e.g., Alabama-Folt and Godwin 2013; Oklahoma-Riedle et al. 2005, East et al. 2014) reported low CPUE of Alligator Snapping Turtles when compared to the numbers documented in Arkansas and Missouri.

The objectives of the present study were to report the findings of a long-term investigation (1995-2015) on a population of Alligator Snapping Turtles inhabiting a single creek (Salado Creek) in northeastern Arkansas. Salado Creek had experienced heavy commercial trapping of Alligator Snapping Turtles prior to 1993, the year in which prohibition of commercial harvesting of the species was enforced by the Arkansas Game and Fish Commission. We present data on abundance, population structure, capture/recapture rates, body condition, growth rates, trapping success, site fidelity, and movement patterns. These data, acquired from trapping results gleaned from 10 separate years over a span of 20 years of sampling within Salado Creek, extend our critical knowledge database on this turtle in Arkansas and provide vital information, range-wide, for managers making prudent status decisions regarding this species.

\section{Materials and Methods}

\section{Study site}

Salado Creek (Fig. 1) is a mostly upland watershed located within the Boston Mountains (Interior Highlands Ecoregion) of the southwest corner of Independence Co., Arkansas. The creek twists and loops greatly after dropping from the higher elevations and is normally navigable by motorized boat only within the lower $5.0 \mathrm{~km}$ stretch of water.

The creek empties into the White River (fed by the hypolimnetic, cold-water release from two U.S Army Corps of Engineers lake impoundments) at a point approximately 9.8 air $\mathrm{km}$ southeast of the White River bridge at Batesville at an elevation of approximately 73 m. Access to the creek was secured from a public boat-launching ramp just below Lock and Dam No. 1 at Batesville. The lower stretch of the creek (sampled for turtles) can be characterized as a turbid, freeflowing, steep-banked stream, nestled 2-5 $\mathrm{m}$ below the rim of its deciduous tree and brush-laden banks. Submerged stumps, numerous root wad entanglements, and creek bank slides were observed yearly. We never witnessed any bank overflows on the creek following 
heavy rain events. Creek depth generally varied between 2-4 m; width ranged from 8-20 m. Depth was lowest during late summer. Log jams and freshly fallen trees often blocked the waterway (Fig. 2) and eventually prevented access to the uppermost reaches of the creek (i.e., trapping locations above No. 33; see Fig. 1). Arkansas State Highway 14 spans $5 \mathrm{~m}$ above the creek at a point approximately $1.5 \mathrm{~km}$ upstream from the White River.

Salado Creek mostly lacks a typical floodplain along much of its lower stretch, as agricultural fields abut its bank rim (Fig. 1A).

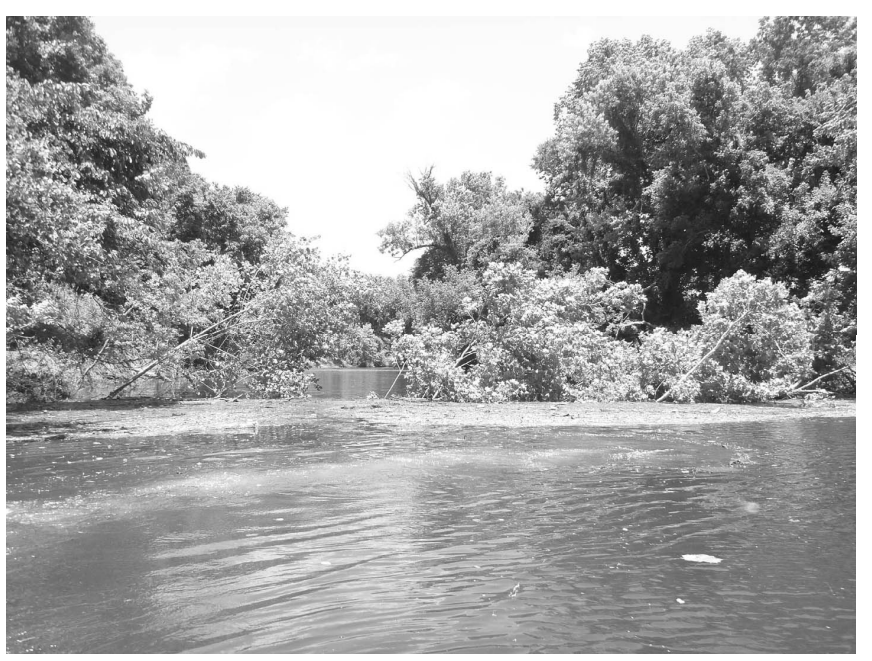

Figure 2. Fallen trees often created temporary logjams across Salado Creek. The trunks of these trees ultimately contribute to the microhabitat and overall cover for Alligator Snapping Turtles.

Forty-one trapping locations were initially assigned to Salado Creek at the beginning of the study in August 1995 (Fig. 1). Linear distance between designated locations averaged $160 \mathrm{~m}$. Locations 34-41 became inaccessible during the 1996 trapping season due to a permanent logjam above location 33; these locations were not visited thereafter.

\section{Trapping methods}

We primarily used $1.2 \mathrm{~m}$ diameter, doublethroated, hoop nets containing a $6.5 \mathrm{~cm}$ mesh spread between 7 fiberglass rings for trapping turtles. Nets were set with extended anterior and posterior lead lines running parallel to the bank (net mouth downstream and submerged). Lead lines were fastened to natural vegetation (i.e., trees and/or root systems) or to steel and wooden stakes. Nets were baited with recentlythawed whole fish or fish parts (mostly buffalo
[Ictiobus sp.]), which were tied to the most posterior hoop using a nylon string strung onto a 16-penny nail used to secure the bait. A breather space was provided at the end of each trap using a gallon plastic flotation jug.

Traps (normally 12 or 13 per sampling episode) were set in late afternoon, left overnight, and then checked the following morning. No traps were left for two consecutive nights. A trap night was defined as a single trap left overnight; the capture rate, CPUE, was determined by dividing the number of turtles by the number of trap nights.

\section{Turtle processing procedures}

For permanent identification, all Alligator Snapping Turtles were tagged with passive integrated transponder (PIT) tags hypodermically injected ventrolaterally into the postanal tail musculature. The following body parameters were measured: straight carapace length (SCL, in $\mathrm{mm}$ ), preanal tail length (PTL, in $\mathrm{mm}$ ), postanal tail length (in $\mathrm{mm}$ ), and body mass (BM, in $\mathrm{kg}$ ). The massive body size of several males trapped on 24 July 2015 prevented measurements of BM (See Fig. 3; Appendix 1). Turtles were released at or near the point of capture. Because curved carapace length (CCL), instead of SCL, was used to measure turtles during the initial part of the present study (Trauth et al. 1998), we computed a linear regression equation using 28 turtles from which we measured both CCL and SCL (turtles captured during 2011-2014). The resulting equation, $\mathrm{Y}=$ $1.0474 \mathrm{X}-9.7831$, where $\mathrm{X}=\mathrm{SCL}$ and $\mathrm{Y}=\mathrm{CCL}$, was generated. We then converted the CCL measurements to SCL of the turtles from 1995-1998 in order to create uniformity in our overall database.

Dobie (1971) found that Louisiana male and female turtles mature at around 370 and $330 \mathrm{~mm} \mathrm{SCL}$, respectively. However, the assignment of sex to live subadult turtles is a difficult task due to the absence of marked sexual differences in morphology in young turtles. We utilized a standard method for sexing Alligator Snapping Turtles-if the cloacal (anal) opening of an individual's straightened tail appeared to lie posterior to the posterior margin of the carapace when viewed ventrally, then the specimen was considered a male; the opposite case would indicate a female. We also utilized PTL to assign sex to subadults: males were considered to possess a longer PTL relative to body size and females, a shorter PTL relative to body size. If there was no clear distinction between the sexes using PTL in subadults, the 
specimen remained unsexable and was labeled a juvenile.

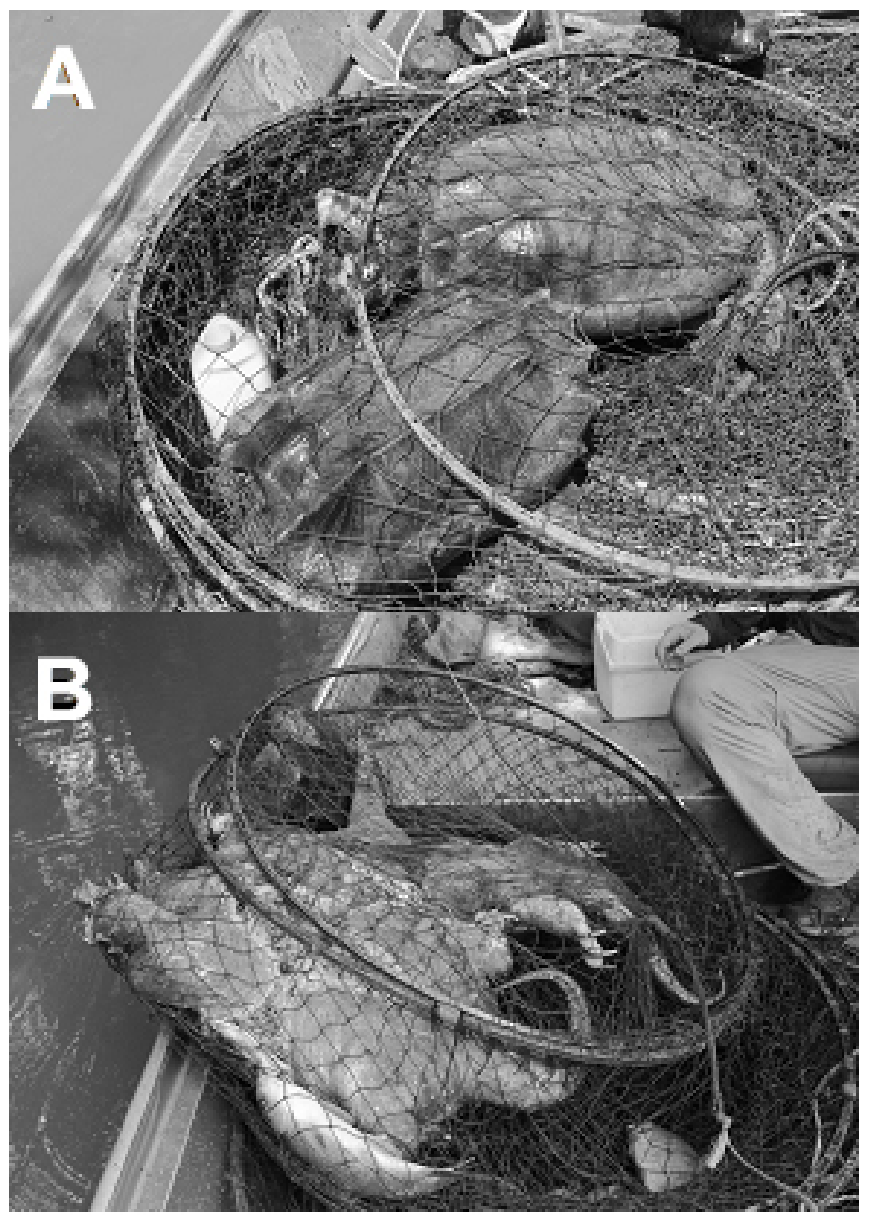

Figure 3. Several large male Alligator Snapping Turtles at trap locations 19 (A) and 17 (B) from Salado Creek photographed on 24 July 2015. No BM measurements were taken from these males (see Appendix 1).

\section{Statistical analyses}

Population size was estimated using Microsoft Excel to calculate the Jolly-Seber population model (Jolly 1965; Seber 1982). Population growth was estimated using linear regression of the CPUE (turtles caught per trap-night) during each sampling year from 1995-2015. Population growth of males and of females was also examined using multiple regression with trapnights and years as predictors because of the complex pattern of population growth compared to males. JollySeber is suited for studies like the present one, in which every individual has the same probability of capture during a given sampling period, the same probability of survival among sampling periods, marks are relatively permanent, and sampling time is negligible in relation to the intervals between samples. In addition, it assumes an open population, thus allowing for immigration, emigration, mortality, and natality (Krebs 1989).

Male and female SCL-BM (body mass) relationships were modeled using regression for all turtles captured during the study. Change in SCL and in body condition of recaptured Alligator Snapping Turtles was statistically analyzed using linear regression. Body condition was estimated by dividing the body mass $(\mathrm{kg})$ by the SCL.

In all analyses, alpha $=0.05$ was significant, alpha $=0.1$ indicated no significant effect, and alpha $>0.05$ but $<0.01$ suggested a possible effect. This method of decision theory follows accepted convention for ecological studies.

\section{Results}

\section{Relative abundance}

We trapped 163 individual Alligator Snapping Turtles over 416 trap nights and recorded a total of 35 recaptures during this study (Appendix 2). Two turtles drowned, and one turtle that was caught by a fisherman in the White River upstream from Salado Creek, was released into the creek. The CPUE averaged slightly greater than 0.24 (317 trap nights) during the first 4 years (1995-1998), showed an increase to 0.64 by 2001 (only 14 trap nights), and then dramatically increased during the final 5 years of this study to average 0.92 ( 85 trap nights).

\section{Population structure}

There was a significant size class difference between the early trapping period vs the more recent period (Fig. 4). Males and females falling into the 351-400 $\mathrm{mm}$ SCL range comprised the greatest number of turtles. A shift toward greater body size in males was evident in the 2011-2015 sampling period.

\section{Population size}

For 1996-2001, the average population size estimate in the sampled portion of Salado Creek was 58 (SE = 14.26) Alligator Snapping Turtles. No population estimate is provided for 1995, because there were no previously marked turtles for that year. The population size estimates ranged from 20 in 1995 to 88 in 1998. For 2011-2015, the average population size estimate in the sampled portion of Salado Creek was 
$131(\mathrm{SE}=39.71)$ turtles. The population size estimates ranged from 105 in 2011 to 282 in 2015.

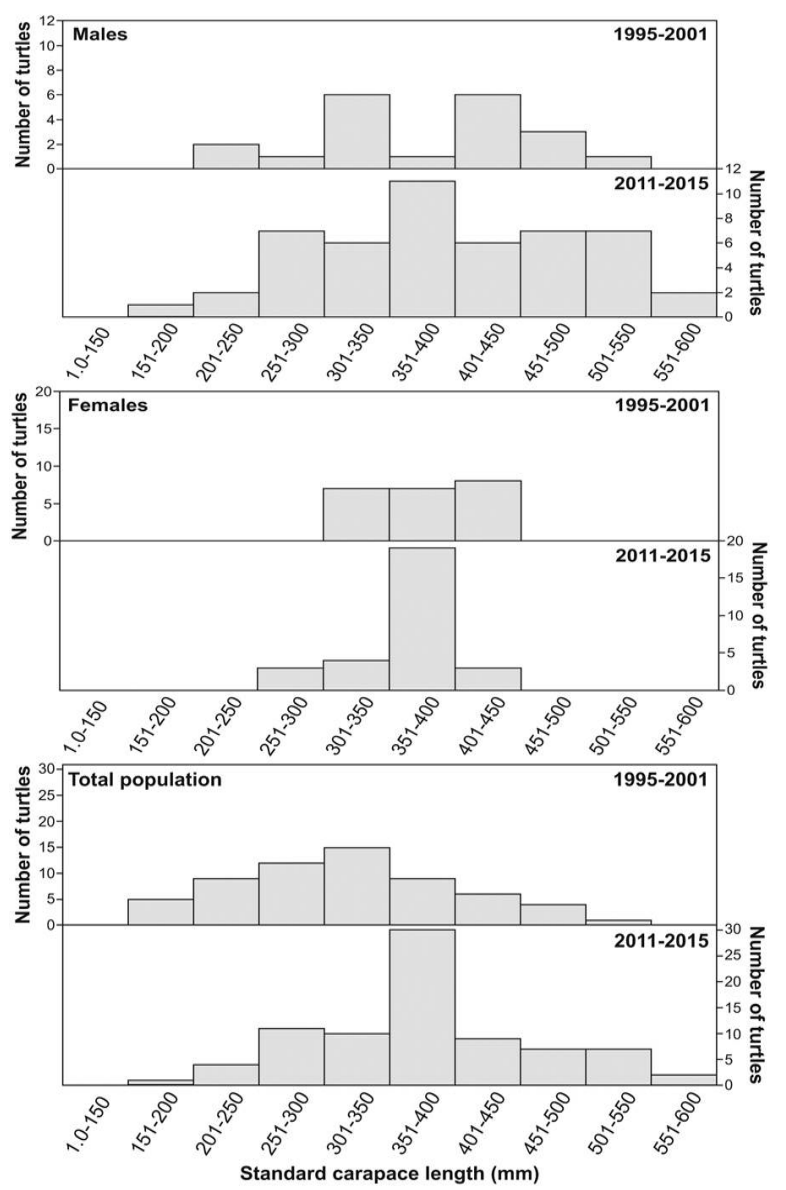

Figure 4. Size-class distribution of Alligator Snapping Turtles trapped during 10 trapping seasons from Salado Creek.

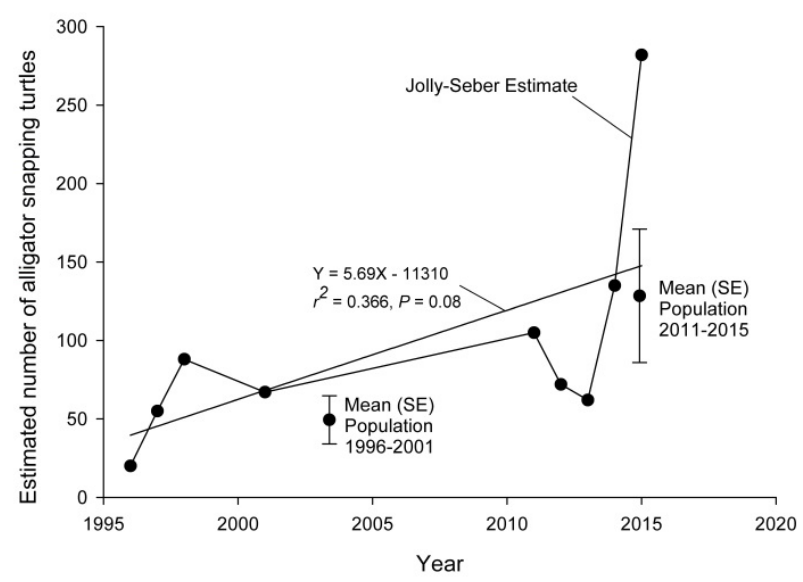

Figure 5. Average population size in the two sampling periods, annual number of Alligator Snapping Turtles trapped, and the regression demonstrating growth in the population in from Salado Creek.

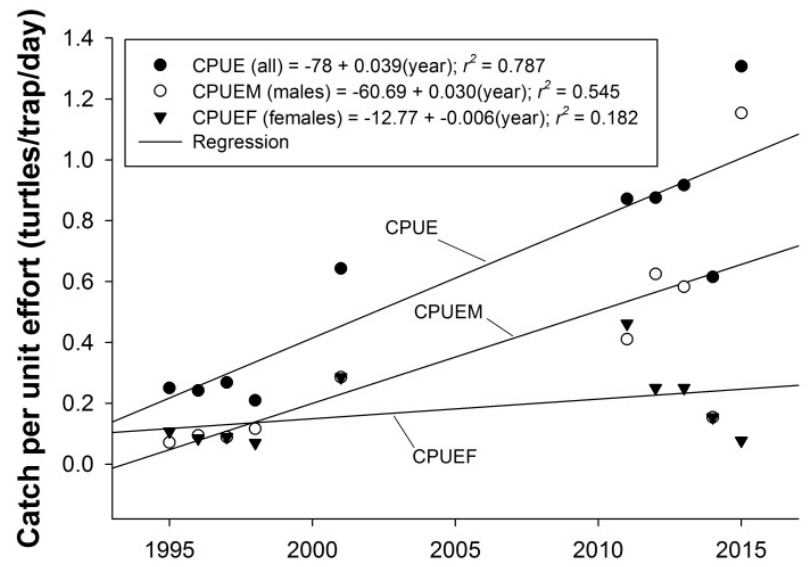

Figure 6. Change in abundance of Alligator Snapping Turtles trapped from Salado Creek based on catch per unit effort (CPUE) over the course of our long-term monitoring.

The population in the lower $5.0 \mathrm{~km}$ of Salado Creek grew significantly from an estimated 5.5-174 turtles/km in 1995-2001 (Fig. 5) to an estimated 21.9-290 turtles $/ \mathrm{km}$ in the ending sampling period (2011-2014).

\section{Did CPUE change during the study?}

The CPUE of Alligator Snapping Turtles increased during 1996-2015 (CPUE $=[0.039 \times$ year $]-78.4 ; \mathrm{r}^{2}=$ 0.787; Fig. 6). The CPUE during $1995-2001$ grew from 0.322 turtles/trap/night $(\mathrm{SE}=0.081)$ to 0.917 turtles/trap/night $(\mathrm{SE}=0.11)$ in 2011-2015 (Fig. 7; $\mathrm{T}=$ $-4.33, \mathrm{P}=0.003)$.

Males became more abundant during the study $\left(\right.$ CPUE $=[0.03 \times$ year $]-60.7 ; \mathrm{r}^{2}=0.545 ;$ Fig. 6$)$. The CPUE for males grew marginally larger from 0.13 (SE $=0.039)$ in $1995-2001$ to $0.585(\mathrm{SE}=0.16)$ in 20112015 (Fig. 7; $\mathrm{T}=-2.68, \mathrm{P}=0.055$ ).

Females abundance was erratic during the study $\left(\mathrm{r}^{2}\right.$ $=0.182$; Fig. 6). Although CPUE of females grew from 1995-2011, it regressed from 2011-2015. Multiple regression suggests that some growth in the female population probably occurred $\left(\mathrm{N}_{\text {females }}=[0.09 \mathrm{x}\right.$ trap-nights $]+[0.18$ x year $\left.]-353 ; \mathrm{r}^{2}=0.496\right)$. However, CPUE in 1995-2001 (mean $=0.1272, \mathrm{SE}=$ 0.40) was not significantly different from CPUE during the 2011-2015 trapping period (mean $=0.238, \mathrm{SE}=$ 0.065; Fig. $7 ; \mathrm{T}=-1.46, \mathrm{P}=0.193$ ).

\section{Did SCL and body condition (BC) change during the study?}

Males were recaptured more frequently than were 
females, thus analyzing these data together may be suspect. The relationship for BM $(\mathrm{kg})$ to $\mathrm{SCL}(\mathrm{mm})$ in males $\left(\mathrm{r}^{2}=0.972\right.$; Fig. 8) was $\mathrm{BM}_{\text {male }}=13.24-(0.114$ $\left.\times \mathrm{SCL}_{\text {male }}\right)+\left(0.0003 \times \mathrm{SCL}_{\text {male }}^{2}\right)$ and for females $\left(\mathrm{r}^{2}=\right.$ 0.745 ; Fig. 8) was $\mathrm{BM}_{\text {female }}=14.40-(0.120 \times$ $\left.\mathrm{SCL}_{\text {female }}\right)+\left(0.0003 \times \mathrm{SCL}_{\text {female }}^{2}\right)$.

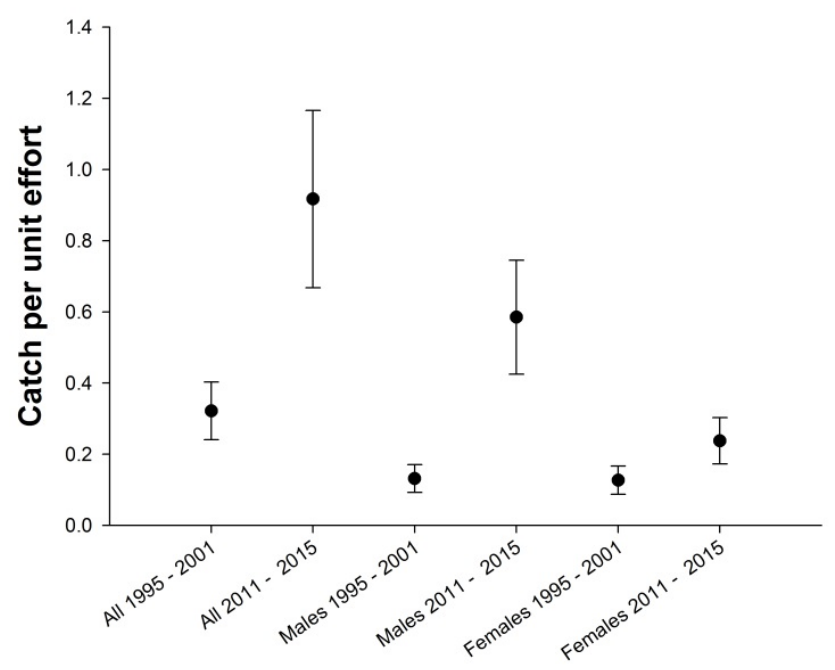

Figure 7. Trapping success for male and female Alligator Snapping Turtles from Salado Creek based upon CPUE.

The SCL for recaptured males showed an average increase of $105 \mathrm{~mm}(\mathrm{SE}=27.6)\left(\mathrm{r}^{2}=0.771\right.$, slope $=$ $0.84 \mathrm{~mm} / \mathrm{mo}$; Fig. 9; Appendix 1) from $322.4 \mathrm{~mm}$ (SE $=34.3)$ to $427.4 \mathrm{~mm}(\mathrm{SE}=20.2)$. Overall male body condition also increased $0.02(\mathrm{SE}=0.004)\left(\mathrm{r}^{2}=0.685\right.$; slope $=0.0001$ units $/ \mathrm{mo} ;$ Fig. 10) from $0.028(\mathrm{SE}=$ $0.006)$ to 0.044 (SE $=0.005)$. The BM-SCL relationship for all males marked suggests that the expected BM for the average SCL observed in the early sampling period should be $7.67 \mathrm{~kg}$, which is 1.25 $\mathrm{SE}$ below the observed BM $(11.37 \mathrm{~kg}, \mathrm{SE}=3.45)$.

The model predicts the $\mathrm{BM}$ for the recaptured males in the second sampling period should be $19.3 \mathrm{~kg}$, which is well within the observed BM $(19.7 \mathrm{~kg}, \mathrm{SE}=$ 2.9) for recaptured males.

The SCL for recaptured females increased 12.17 $\mathrm{mm}(\mathrm{SE}=5.8)\left(r^{2}=0.510 ;\right.$ slope $=0.159 \mathrm{~mm} / \mathrm{mo} ;$ Fig . 7) from $340.8 \mathrm{~mm}(\mathrm{SE}=7.2)$ to $353 \mathrm{~mm}(\mathrm{SE}=9.3)$. Female body condition rose 0.003 units $(\mathrm{SE}=0.0004)$ $\left(r^{2}=0.257\right.$; slope $=7.2 \times 10^{-6}$; Fig. 10) from 0.027 units $(\mathrm{SE}=0.027)$ to 0.03 units $(\mathrm{SE}=0.001)$. The BM-SCL relationship for all females marked suggests that the predicted BM for the SCL observed in the early sampling period should be $8.35 \mathrm{~kg}$, which is 1.58 SE lower than the observed BM $(9.22 \mathrm{~kg}, \mathrm{SE}=0.55)$ for females from the early sampling period that were
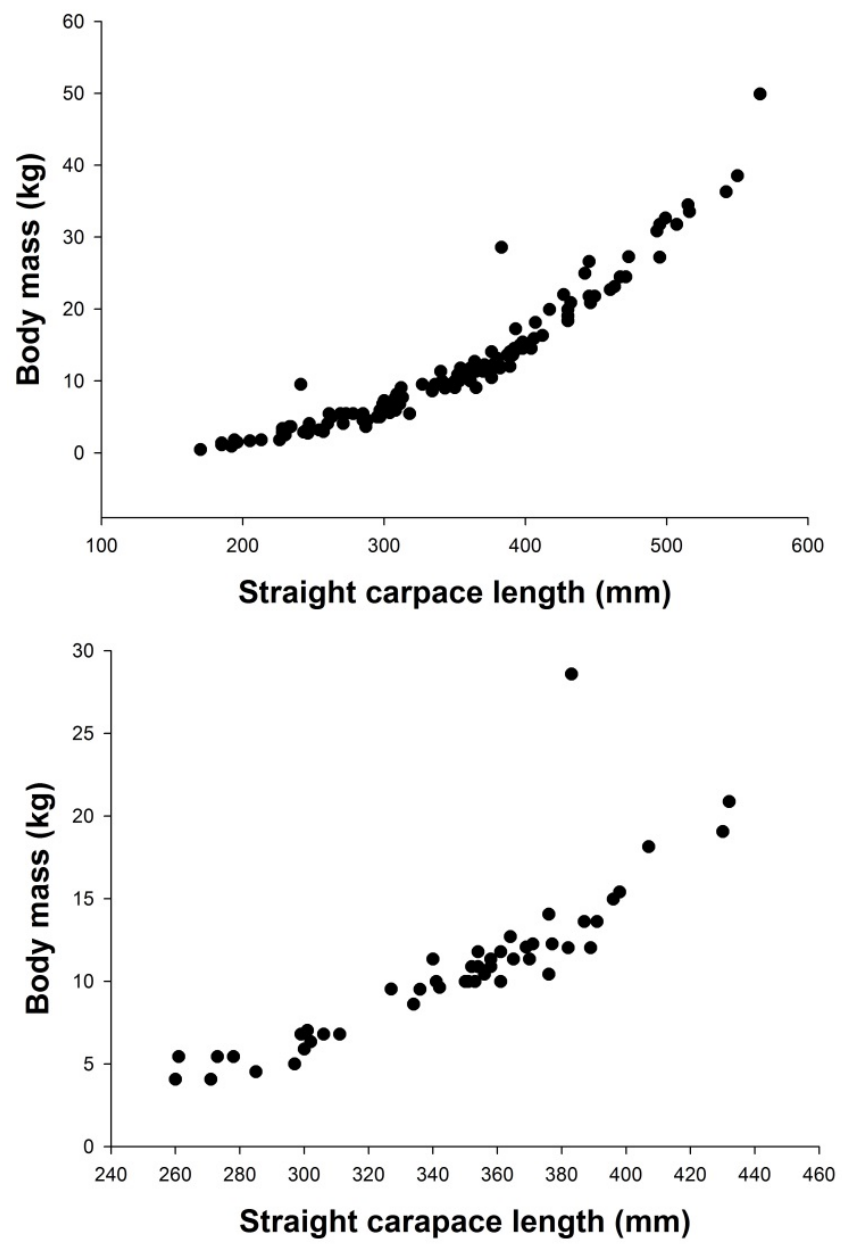

Figure 8 . Relationship between body mass and straight carapace length in males (upper plot) and female (lower plot) Alligator Snapping Turtles from Salado Creek.

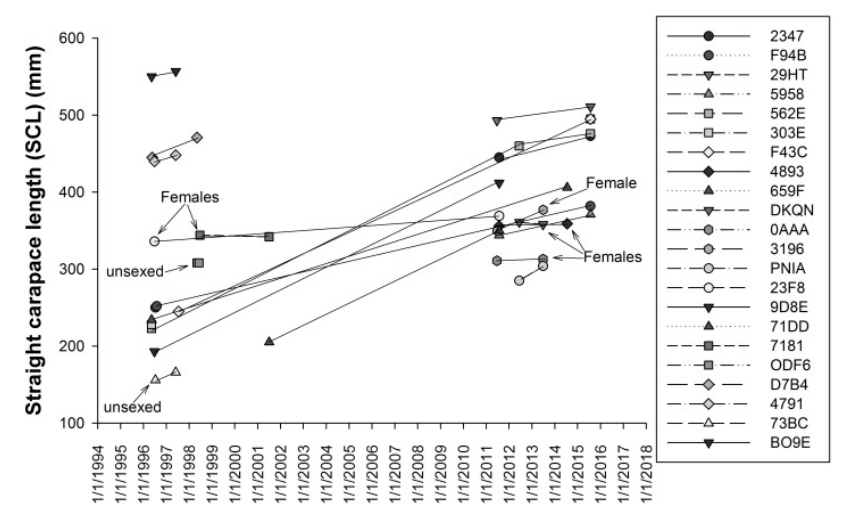

Figure 9. Change in straight carapace length in recaptured Alligator Snapping Turtles from Salado Creek (see also Appendix 1).

The SCL for recaptured females increased 12.17 $\mathrm{mm}(\mathrm{SE}=5.8)\left(r^{2}=0.510 ;\right.$ slope $=0.159 \mathrm{~mm} / \mathrm{mo} ;$ Fig . 7) from $340.8 \mathrm{~mm}(\mathrm{SE}=7.2)$ to $353 \mathrm{~mm}(\mathrm{SE}=9.3)$. 


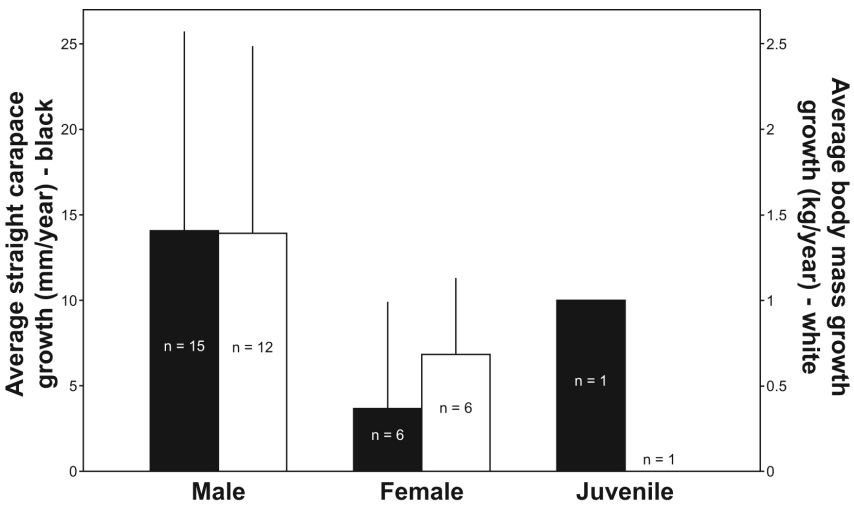

Figure 10. Body condition of male, female, and juvenile Alligator Snapping Turtles from Salado Creek

Female body condition rose 0.003 units $(\mathrm{SE}=$ $0.0004)\left(r^{2}=0.257\right.$; slope $=7.2 \times 10^{-6}$; Fig. 10 $)$ from 0.027 units $(\mathrm{SE}=0.027)$ to 0.03 units $(\mathrm{SE}=0.001)$. The BM-SCL relationship for all females marked suggests that the predicted BM for the SCL observed in the early sampling period should be $8.35 \mathrm{~kg}$, which is 1.58 SE lower than the observed BM $(9.22 \mathrm{~kg}, \mathrm{SE}=$ $0.55)$ for females from the early sampling period that were later recaptured. The model predicts the BM for the recaptured females in the second sampling period should be $9.42 \mathrm{~kg}$, which is $1.8 \mathrm{SE}$ lower than the observed $\mathrm{BM}(10.7 \mathrm{~kg}, \mathrm{SE}=0.71)$ for recaptured females.

\section{Growth rate}

The male turtles recaptured had a higher average growth rate in both straight carapace length and mass (Fig. 10) than in females or juveniles. These data, however, should be used with caution as age was not known. However, these data are most likely not representative of the growth rates of males and females as turtle age was not possible to record (also see Moore et al. 2012). Males with a starting SCL below $300 \mathrm{~mm}$ exhibited high growth rates $(19.85 \mathrm{~mm} /$ year; $\mathrm{n}=7)$ from time of first capture to next capture while males over $300 \mathrm{~mm}$ exhibited relatively low growth rates $(7.37 \mathrm{~mm} /$ year; $\mathrm{n}=8)$. No female under $300 \mathrm{~mm}$ SCL was recaptured; thus, the difference in growth rates between the sexes is undoubtedly, in part, due to size at first capture, which is most likely correlated to age at first capture.

One recaptured male had a puzzling growth rate. The specimen (F94B; Appendix 1) was first captured on 10 July 1996 and then 20 years later on 24 July 2015. The latter date yielded body measurements that were not compatible with other males recaptured during the same time frame (e.g., specimen 562E). This unusual male had a SCL of $382 \mathrm{~mm}$, a PTL of 130 $\mathrm{mm}$, and a $\mathrm{BM}$ of ca. $11.8 \mathrm{~kg}$, whereas $562 \mathrm{E}$ had a SCL of $476 \mathrm{~mm}$, a PTL of $195 \mathrm{~mm}$, and a BM of at least $28 \mathrm{~kg}$ (actual mass not measured). Body measurements for a comparable female trapped on 24 July 2015 were of expected values $(\mathrm{SCL}=376 \mathrm{~mm}$; $\mathrm{PTL}=83 \mathrm{~mm} ; \mathrm{BM}=10.4 \mathrm{~kg}$ ).

\section{Trapping success}

We documented trapping success rate based upon trap location and distance upstream from the White River (Fig. 11; Appendix 3) We found that trap locations downstream from St. Hwy 14 (starting just below location 10) were the least productive. Fifty-one trap nights in this lower region of the creek yielded only 3 turtles (CPUE $=0.06$ ). Although trap locations 14-24 were trapped the most intensely and were the most productive, turtle-wise, yielding 125 turtles during 236 trap nights $(\mathrm{CPUE}=0.53)$, traps 25-33 produced the highest CPUE (0.67) during 40 trap nights. Traps 10-13 produced only 20 turtles (CPUE = 0.24 ) during 85 trap nights. Trapping success was clearly related to distance away from the White River (Fig. 11).

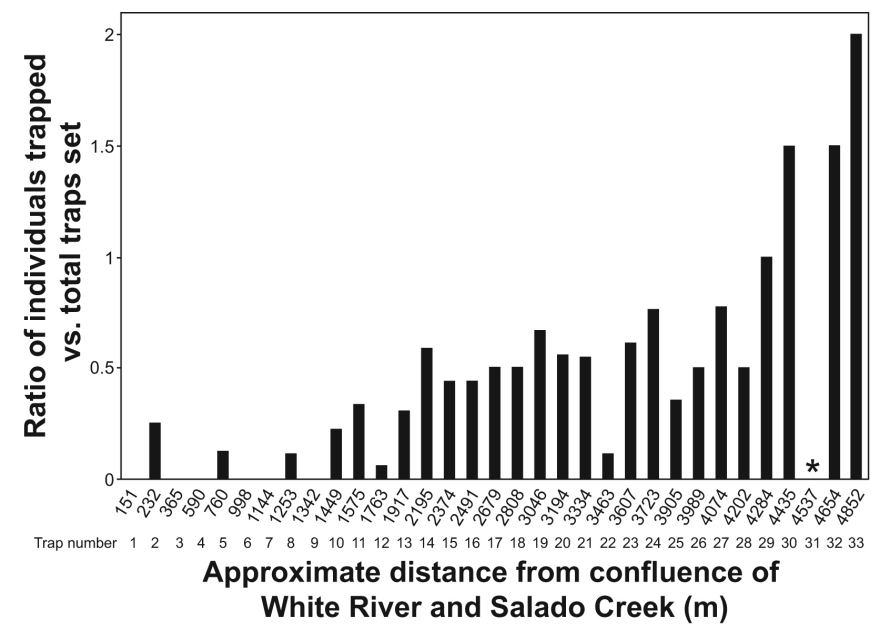

Figure 11. Trapping success of Alligator Snapping Turtles from Salado Creek based upon turtle captures. (*No traps were set at trap location 33.)

\section{Site fidelity and movements}

Most of the 22 recaptured Alligator Snapping Turtles (following the 1996 trapping season) exhibited some degree of site fidelity. Females, however, ventured farther away from a particular trap location 
more often and to a greater distance than did males (Appendix 1). Eight of 14 males showed a preference to remain at a locality (i.e., within the expanse of 1-2 trapping locations). Surprisingly, one subadult male (F94B) was captured on 10 July 1996 at trap location 24 and recaptured at the same location on 24 July 2015. Moreover, another subadult male (71DD), taken from trap location 18 on 2 July 2001, was recaptured at the same location on 26 July 2011. One of the largest adult males (BO9E), however, moved from trap location 19 on 10 May 1996 to location 24 on 30 May 1997 (a distance of $9.71 \mathrm{~km}$ ). Females, on the other hand, were less inclined to remain in a particular area of the creek. For example, an adult female (4893) was captured at trap location 23 on 26 July 2011 and recaptured 17 July 2014, approximately $1.76 \mathrm{~km}$ downstream, at location 11. Another adult female (3196) moved in the opposite direction, going from trap location 14 on 26 July 2011 to location 21 on 27 June 2013 (a distance of approximately $0.96 \mathrm{~km}$ ). These are but a few examples of the movement patterns exhibited by Alligator Snapping Turtles detected by our mark-recapture technique. (For seasonal movement patterns of Alligator Snapping Turtles in Salado Creek in 1996, see Trauth et al. 1998).

\section{Discussion}

A plethora of field studies generated in recent years has sought to address concerns over the legal status as well as the lack of relevant life history information on wild and reintroduced populations of Alligator Snapping Turtles throughout the species' range (Reed et al. 2002; Riedle et al. 2005, 2006, 2008a, 2008b, 2009; Shipman and Riedle 2008; Howey and Dinkelacker 2009; Bogosian 2010; East et al. 2013; Folt and Godwin 2013; Howey and Dinkelacker 2013; Lescher et al. 2013; Moore et al. 2013; Anthony et al. 2015). Our study, however, is the first markrecapture investigation to examine a single, historically harvested population through an extended long-term monitoring period.

Declines in some turtle populations have been linked to the removal of the largest turtles for human consumption, regardless of sex (Nickerson and Pitt 2012). We found that the population structure of Alligator Snapping Turtles in Salado Creek shifted toward larger body size and greater numbers in both adult males and females greater than $325 \mathrm{~mm}$ SCL, but especially in adult males, during the 2011-2015 sampling years - an indication that some stability had returned to this population following a major depletion of larger individuals (Trauth et al. 1998). In addition, the sex ratio strongly favored males (1.8:1) during the latter sampling period, and the overall sex ratio for the study (1.4:1) also remained in favor of males. In contrast, Howey and Dinkelacker (2013), in their 20052007 sampling period in a central Arkansas stream found a sex ratio in favor of females (1:6.1). Likewise, Folt and Godwin (2013) in Alabama also recorded a sex ratio in favor of females (1:1.8). One might easily conclude that, in these particular cases, harvesting large adult males contributed to these observed femalebiased sex ratios (as mentioned in both studies). At present, however, it is unclear why sex ratios favored males in Salado Creek, although Howey and Dinkelacker (2013) suggest that female-biased sex ratios could be the result of a suite of conditions from unequal hatchling sex ratios and differential immigration and emigration to differential mortality of the sexes and possibly trap bias (Gibbons 1990). The unexpected and very striking 15:1 sex ratio in favor of adult males found in our single day of sampling in 2015, however, requires additional explanations and plausibly contradicts a previous suggestion that intrasex competition could contribute to female-biased ratios due to an increased mortality rate in males (Harrel et al. 1996).

A comparison of the Salado Creek population size with that found in a comparable eastern Oklahoma study (East et al. 2013) revealed major differences in numbers at the beginning and at the end of sampling. In our study, a shift toward greater numbers and larger turtles occurred; however, in Oklahoma, just the opposite was true as that population experienced an overall decline. For example, our 2011-2015 data resembles that published by Riedle et al. (2008) for their 1997-2000 densities, whereas our 1995-2001 population numbers roughly matched the 2010-2011 data published by East et al. (2013). With respect to size-class structure, our study found an increase in number of turtles in the 351-400 $\mathrm{mm}$ SCL range, and East et al. (2013) found that size range was highly underrepresented.

Our overall CPUE was 0.39; however, we found a steady rise in CPUE from 0.24 (1995-1998) to 0.92 during the final 5 years of this study. In reporting a CPUE of 0.478 for the Fowl River in Alabama, Folt and Godwin (2013) suggested that their value there possibly represented historic population conditions prior to commercial trapping, although they attributed this greater relative abundance partially to a paired-net method of trapping. This value was much greater than 
their overall CPUE value of 0.062 .

We found that both CPUE and Jolly-Seber approaches demonstrate that the Salado Creek population benefitted from removal of harvesting pressure, thus leading to an increase in abundance of Alligator Snapping Turtles. These data indicate a sharp increase in the number of all sizes of turtles compared to previous findings from this population (Trauth et al. 1998).

Our results indicate that recaptured males had higher BC scores by the end of the study. However, the $\mathrm{BC}$ was much higher in the early period than it was in the later period relative to the model's prediction. This suggests that males are now experiencing more stress than earlier. The improvement in female body condition may reflect alleviation of stress from fishing pressure or other unknown factors during the study, although turtles in both periods appeared well nourished. In fact, the females in this population appeared well nourished (i.e., higher BCI) in both sampling periods with females in the second sampling period exhibiting a $12.2 \%$ higher BCI than observed in the early sampling period. Because males seem to be experiencing reduced relative body condition and females are more nourished, we can speculate that this may reflect increased male-male competition and aggression as the growing male population leads to increased opportunities for interactions, aggression and competition. Male-male competition could result from an interspecific source. Johnston et al. (2012) mentioned the possibility that in their population of Chelydra serpentina, agonistic encounters between $C$. serpentina and Macrochelys temminckii might be occurring, given the number of Alligator Snapping Turtles $(n=84)$ they trapped and the necessity for the two species of chelydrids to coexist. We captured a relatively small number of $C$. serpentina $(n=6)$ during our study and have no supportive evidence to indicate any encounters. Interestingly, however, one of these was an adult male reported by McCallum and Trauth (2003), which was PIT tagged in 1996 and recaptured at the very same trap location (10) in 2001. The turtle had experienced a reduction in post-anal tail length of $18 \mathrm{~mm}$; the tail also appeared to have healed and had regrown from the initial injury.

One of the more salient outcomes from our study pertained to site fidelity and habitat selection. A majority of recaptured males were trapped at or near their original collection site. One extreme example was a 20 -year span between recaptures for a male at the same trapping location. Howey and Dinkelacker (2009) reported that males and females probably select similar habitats (submerged structure) having similar thermal properties. A majority of turtles captured during our study was trapped upstream from location 14. Submerged logs, root wads, and tree stumps were generally available throughout most parts of the creek; however, the lower stretch (below location 10) was presumably impacted by the cooler water of the White River and represented suboptimal thermal conditions for the turtles. Our trapping success in this region was the lowest value for the entire creek.

A reduced vagility in most recaptured turtles was observed (based upon recaptures during the 20112015) when compared to the considerable upstream and downstream movements found in 1996 (Trauth et al. 1998). Adult females, however, appeared to move more than adult males; this observation was similar to the results found in southeast Missouri (Shipman and Riedle 2008). Linear home ranges of the Missouri turtles were much larger than those in our study, which may account for and/or play a role in movement behavior. This new finding does suggest, however, that Alligator Snapping Turtles may venture away from preferred microhabitat sites when population numbers are low or when searching for a mate, but will return to and/or remain within a familiar microhabitat when population numbers stabilize or when mates are easily accessible. Food availability was never considered a contributing factor in addressing movement patterns in these turtles in Salado Creek primarily, because of an assortment of fishes (mostly Ictiobus sp.) was always a by-catch of our trapping efforts. Our observations on movement patterns of Alligator Snapping Turtles confined within a mostly "closed" creek population differed sharply from most other studies examining movements in this species (e.g., Riedle et al. 2006). Consequently, in order to understand the wide variations in turtle movements, future studies might benefit greatly by investigating this turtle strictly in a creek habitat similar to ours.

\section{Acknowledgments}

We thank the Arkansas Game and Fish Commission, and especially Kelly Irwin, for written permission to investigate Alligator Snapping Turtles in Salado Creek through the authority of annual Scientific Collection Permits granted to SET. The Department of Biological Sciences at Arkansas State University provided financial assistance during this study; J. D. Wilhide, B. J. Ball, C. Lewis, H. H. Trauth, and K. S. Trauth assisted in the field. Chris Thigpen kindly offered technical assistance during manuscript

\section{Journal of the Arkansas Academy of Science, Vol. 70, 2016}


preparation; we also thank J. D. Riedle for his constructive comments on the manuscript and for the sharing of his knowledge about Alligator Snapping Turtles. Lastly, we dedicate this paper to the memory of Robert "Champ" Williams, Arkansas videographer and Emmy-award winning marine documentarian, who drowned 8 November 2015 in a filming tank while gathering underwater footage of a large Alligator Snapping Turtle.

\section{Literature Cited}

Anthony T, JD Riedle, MB East, B Fillmore and DB Ligon. 2015. Monitoring of a reintroduced population of juvenile alligator snapping turtles. Chelonian Conservation and Biology 14:43-48.

Bogosian V, III. 2010. Natural history of resident and translocated alligator snapping turtles (Macrochelys temminckii) in Louisiana. Southeastern Naturalist 9:711-720.

Congdon JD, AE Dunham and RC van Loben Sels. 1994. Demographics of common snapping turtles (Chelydra serpentina): implications for conservation and management of long-lived organisms. American Zoologist 34:397-408.

East MB, JD Riedle and DB Ligon. 2013. Temporal changes in an alligator snapping turtle (Macrochelys temminckii) population. Wildlife Research 40:77-81.

Folt B and JC Godwin. 2013. Status of the alligator snapping turtle (Macrochelys temminckii) in south Alabama with comments on its distribution. Chelonian Conservation and Biology 12:211-217.

Gibbons, JW. 1990. Sex ratios and their significance among turtle populations, p. 171-182. In Life history and ecology of the slider turtle. J W Gibbons (ed.). Smithsonian Institution Press, Washington, D.C.

Gibbs JP and DA Steen. Trends in sex ratios of turtles in the United States: implications of road mortality. Conservation Biology 19:552-556.

Harrel, JB, CM Allen and SJ Hebert. 1996. Movements and habitat use of subadult alligator snapping turtles (Macroclemys temminckii) in Louisiana. American Midland Naturalist 135:60-67.

Hoffman M, C Hilton-Taylor, A Angulo, M Böhm, TM Brooks, SHM Butchart, KE Carpenter, et. al. 2010. The impact of conservation on the status of the world's vertebrates. Science 330:1503-1509.
Howey CAF and SA Dinkelacker. 2009. Habitat selection of the alligator snapping turtle (Macrochelys temminckii) in Arkansas. Journal of Herpetology 43:589-596.

Howey CAF and SA Dinkelacker. 2013. Characteristics of a historically harvested alligator snapping turtle (Macrochelys temminckii) population. Copeia 2013:58-63.

Johnston GR, E Suarez, JC Mitchell, GA Shemitz, PL Butt and M Kaunert. 2012. Population ecology of the snapping turtle (Chelydra serpentina) in a northern Florida river. Bulletin of the Florida Museum of Natural History 51:243-256.

Jolly GM. 1965. Explicit estimates from capturerecapture data with both death and immigrationstochastic model. Biometrika 1965:225-247.

Lescher TC, JT Briggler and Z Tang-Martínez. 2013. Relative abundance, population structure, and conservation of alligator snapping turtles (Macrochelys temminckii) in Missouri. Chelonian Conservation and Biology 12:163-168.

Liner EA. 2005. The Culinary Herpetologist. Bibliomania, Salt Lake City, UT. 382 p.

McCallum ML and SE Trauth. 2003. Chelydra serpentina (Common Snapping Turtle). Site fidelity and growth. Herpetological Review 34:228.

Moore DB, DB Ligon, BM Fillmore and SF Fox. 2013. Growth and viability of a translocated population of alligator snapping turtles (Macrochelys temminckii). Herpetological Conservation and Biology 8:141-148.

Nickerson MA and AL Pitt. 2012. Historical turtle population decline and community changes in an Ozark river. Bulletin of the Florida Museum of Natural History 51:257-267.

Pritchard PCH. 1989. The Alligator Snapping Turtle Biology and Conservation. Milwaukee Public Museum, Milwaukee, WI. 104 p.

Pritchard PCH. 2006. The Alligator Snapping Turtle Biology and Conservation. Krieger Publishing Co., Malabar, FL, 140 p.

Reed RH, J Congdon and JW Gibbons. 2002. The alligator snapping turtle [Macrochelys (Macroclemmys temminckii)]: a review of ecology, life history and conservation with demographic analysis of the sustainability of take from wild populations. Savannah River Ecology Lab., Univ. of Georgia. A Report to Division of Scientific Authority, US Fish and Wildlife Service, pp. 1-29. 
Riedle JD, PA Shipman, SF Fox and DM Leslie Jr. 2005. Status and distribution of the alligator snapping turtle, Macrochelys temminckii, in Oklahoma. Southwestern Naturalist 50:79-84.

Riedle JD, PA Shipman, SF Fox and DM Leslie Jr. 2006. Microhabitat use, home range, and movements of the alligator snapping turtle, Macrochelys temminckii, in Oklahoma. Southwestern Naturalist 51:35-40.

Riedle JD, DB Ligon and K Graves. 2008a. Distribution and management of alligator snapping turtles, Macrochelys temminckii, in Kansas and Oklahoma. Transactions of the Kansas Academy of Science 111:21-28.

Riedle JD, PA Shipman, SF Fox, JC Hackler and DM Leslie Jr. 2008b. Population structure of the alligator snapping turtle, Macrochelys temminckii, on the western edge of its Distribution. Chelonian Conservation and Biology 7:100-110.
Seber GAF. 1982. The Estimation of Animal Abundance and Related Parameters. 2nd ed. Macmillan Publ. Co., New York, NY, 654 p.

Trauth SE, JD Wilhide and A Holt. 1998. Population structure and movement patterns of alligator snapping turtles (Macroclemys temminckii) in northeastern Arkansas. Chelonian Conservation and Biology 3:64-70.

Trauth SE, HW Robison and MV Plummer. 2004. The amphibians and reptiles of Arkansas. University of Arkansas Press, Fayetteville. 421 p. 
S.E. Trauth, D.S. Siegel, M.L. McCallum et. al.

Appendix 1. Mark-recapture data on 22 alligator snapping turtles sampled from Salado Creek (1996-2015) including PIT tag identification code (last 4 alpha-numerics of the original code), date of capture, trap location, sex, straight carapace length, and body mass.

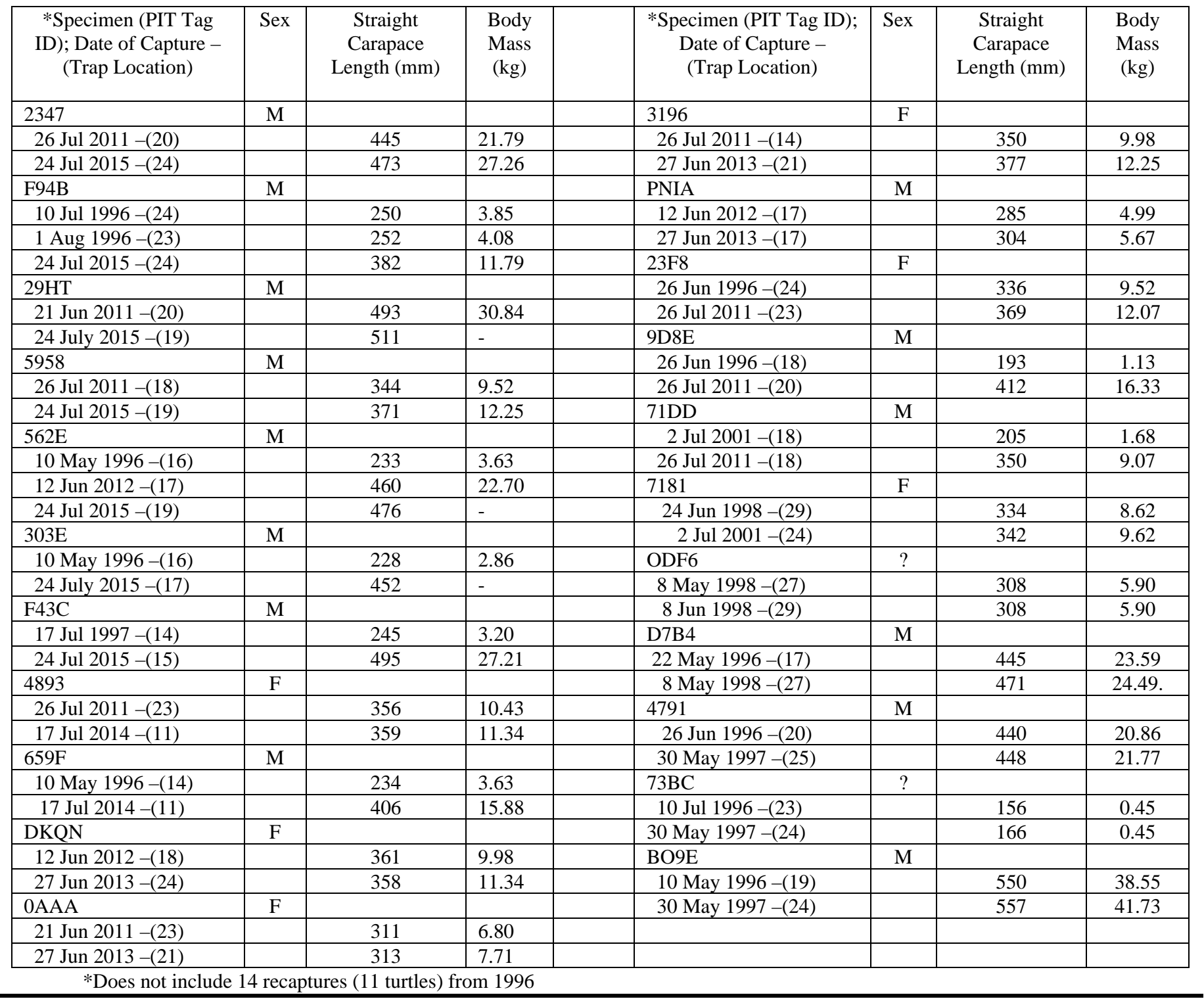


Journal of the Arkansas A cademy of Science, Vol. 70 [2016], Art. 39

Long-term Monitoring of Alligator Snapping Turtles

Appendix 2. Yearly sampling data for alligator snapping turtles from Salado Creek (*Excludes recaptures; **Excludes multiple recaptures.)

\begin{tabular}{|c|c|c|c|c|c|}
\hline Year & $\begin{array}{c}\text { Total No. of } \\
\text { Trap Nights }\end{array}$ & $\begin{array}{c}\text { Total No. of Trapped } \\
\text { Alligator Snapping } \\
\text { Turtles }\end{array}$ & $\begin{array}{c}* \text { Sex Ratio } \\
\text { (male:female) }\end{array}$ & $\begin{array}{c}* * \text { No. of } \\
\text { Recaptures }\end{array}$ & $\begin{array}{c}\text { Catch Per } \\
\text { Unit Effort } \\
\text { (CPUE) }\end{array}$ \\
\hline 1995 & 28 & 7 & $2: 3$ & 0 & 0.25 \\
\hline 1996 & 190 & 46 & $18: 16$ & 15 & 0.24 \\
\hline 1997 & 56 & 15 & $5: 5$ & 7 & 0.27 \\
\hline 1998 & 43 & 9 & $5: 3$ & 2 & 0.21 \\
\hline 2001 & 14 & 9 & $4: 4$ & 0 & 0.64 \\
\hline 2011 & 39 & 34 & $16: 18$ & 4 & 0.87 \\
\hline 2012 & 8 & 7 & $5: 2$ & 1 & 0.88 \\
\hline 2013 & 12 & 11 & $3: 3$ & 4 & 0.92 \\
\hline 2014 & 13 & 8 & $15: 1$ & 2 & 0.62 \\
\hline 2015 & 13 & 17 & $80: 57$ & 35 & 1.31 \\
\hline Totals & 416 & 163 & & & $\overline{\mathrm{x}}=0.62$ \\
\hline
\end{tabular}

Appendix 3. Trapping success at 32 trap locations (no traps set at location 31) on Salado Creek.

\begin{tabular}{|c|c|c|c|c|c|}
\hline $\begin{array}{c}\text { Trap } \\
\text { Location }\end{array}$ & $\begin{array}{l}\text { Total Number } \\
\text { of Traps Set } \\
\text { at Location }\end{array}$ & $\begin{array}{c}\text { Total Number of } \\
\text { Turtles Trapped } \\
\text { at Location }\end{array}$ & $\begin{array}{c}\text { Trap } \\
\text { Location }\end{array}$ & $\begin{array}{c}\text { Total Number } \\
\text { of Traps Set at } \\
\text { Location } \\
\end{array}$ & $\begin{array}{c}\text { Total Number of } \\
\text { Turtles Trapped at } \\
\text { Location }\end{array}$ \\
\hline 1 & 3 & 0 & 18 & 28 & 14 \\
\hline 2 & 4 & 1 & 19 & 21 & 14 \\
\hline 3 & 4 & 0 & 20 & 18 & 10 \\
\hline 4 & 6 & 0 & 21 & 22 & 12 \\
\hline 5 & 8 & 1 & 22 & 18 & 2 \\
\hline 6 & 7 & 0 & 23 & 18 & 11 \\
\hline 7 & 3 & 0 & 24 & 17 & 13 \\
\hline 8 & 9 & 1 & 25 & 17 & 6 \\
\hline 9 & 7 & 0 & 26 & 4 & 2 \\
\hline 10 & 27 & 6 & 27 & 9 & 7 \\
\hline 11 & 18 & 6 & 28 & 2 & 1 \\
\hline 12 & 17 & 1 & 29 & 3 & 3 \\
\hline 13 & 23 & 7 & 30 & 2 & 3 \\
\hline 14 & 29 & 17 & 31 & 0 & 0 \\
\hline 15 & 16 & 7 & 32 & 2 & 3 \\
\hline 16 & 25 & 11 & 33 & 1 & 2 \\
\hline 17 & 28 & 14 & Totals & 416 & $* 175$ \\
\hline
\end{tabular}

